\title{
Effects of violent political conflict on the supply, demand and fragmentation of fresh food markets
}

\author{
Ziv Bar-Nahum $^{1} \cdot$ Israel Finkelshtain ${ }^{1} \cdot$ Rico Ihle $^{2}$ (D) Ofir D. Rubin $^{3}$ (D)
}

Received: 17 May 2019 / Accepted: 10 March 2020 / Published online: 8 April 2020

(C) The Author(s) 2020

\begin{abstract}
Violent political conflict has been documented to have comprehensive adverse effects on economic activity and, thus, substantially harm social welfare. As conflict escalations are often reported to fragment economic space, we suggest an empirical framework which allows for estimating changes in the size of markets often split by frontlines. This approach uses a differentiated goods oligopoly model to separate effects of conflict intensity on consumer demand, costs of trade, market size, and market structure. We combine daily sales of apples in Hebron - one of the focal points of the Israeli-Palestinian conflict - and variables quantifying complementary aspects of conflict intensity. Conflict is found to suppress demand and affect competition more significantly than it increases costs of trading. Simulations indicate a $15 \%$ reduction in total daily consumption during conflict of high intensity while a pacification would yield a $20 \%$ welfare gain. This empirical framework allows disentangling the effects of conflict on food markets. The results suggest that relief policies should consider alleviating effects of fragmentation of economic space, e.g., by ensuring humanitarian corridors.
\end{abstract}

Keywords Changes in market size $\cdot$ Conflict $\cdot$ Differentiated goods $\cdot$ Economic space $\cdot$ Food demand $\cdot$ Fresh food marketing . Israeli-Palestinian conflict $\cdot$ MENA $\cdot$ Palestine

JEL D74 $\cdot \mathrm{L} 11 \cdot \mathrm{L} 13 \cdot \mathrm{L} 66 \cdot \mathrm{Q} 11$

\section{Introduction}

Violent political conflict is a widespread phenomenon in the developing world (World Bank 2011). Blattman and Miguel (2010) comprehensively review the state of the art of research

Electronic supplementary material The online version of this article (https://doi.org/10.1007/s12571-020-01025-y) contains supplementary material, which is available to authorized users.

Rico Ihle

rico.ihle@wur.nl

1 Department of Environmental Economics and Management, The Robert H. Smith Faculty of Agriculture, Food and Environment, Hebrew University of Jerusalem, Jerusalem, Israel

2 Agricultural Economics and Rural Policy Group, Social Sciences Group, Wageningen University, 6706, KN Wageningen, The Netherlands

3 Department of Public Policy and Administration, Guilford Glazer Faculty of Business and Management, Ben-Gurion University of the Negev, Be'er Sheva, Israel on economic consequences and causes of conflict. They stress that "micro-level analysis and case studies are also crucial to decipher war's causes, conduct, and consequences" (Blattman and Miguel 2010, p. 3). In those countries heavily affected by violent political conflict, large parts of the population are poor and food purchases account for significant shares of household expenditures (Aitchison and Brown 1954). Thus, violent conflict often substantially impairs the availability, access and stability dimensions of the Right to Food (World Bank 2011; EC-FAO 2008). We focus on analysing consequences of conflict on economic and physical access to food, that is, the second dimension of food security (EC-FAO 2008, p. 1). We assess implications for economic and physical access to food as this is one of the core aspects often being reported to be impeded in during conflict escalations causing transitory food insecurity.

Existing research, such as the one conducted, for example, in the framework of Microcon (2018), takes a broad and interdisciplinary social-science perspective without zooming in on food markets in particular. We add to the limited recently emerged literature that analyses micro-economic effects of 
conflict on food demand and supply acknowledging the role the food economy plays in the countries affected where food accounts for relatively more in household expenditures (Seale et al. 2003).

We contribute to closing this gap by disentangling the effects of violent conflict into four aspects of which one of them is changes in market size. This aspect is of great importance as movement restrictions and physical threats often fragment markets by preventing market access in areas subject to escalations of political violence (WFP 2009; UNCTAD 2014).

This analysis contributes to the literature in several ways. Although selected effects of violent political conflict on food markets have been studied by a small literature (e.g., D'Souza and Jolliffe 2013; Ihle and Rubin 2013), differentiated goods oligopoly pricing and demand models (Berry 1994; Berry et al. 1995) have not been used so far for decomposing the impact of conflict intensity on food demand and pricing. We tailor the model to account for food markets becoming temporarily fragmented due to conflict as such transient partitioning of economic space is frequently being reported by international organizations.

As consumers in low-income countries spend on average a higher share of their total food expenditures on fruits and vegetables than consumers in high-income countries (Seale, Regmi and Bernstein 2003, Table 3), we focus on fruits. In particular, we analyse daily quantities and prices of apples traded in the Hebron wholesale market between May 2007 and September 2010. We measure complementary aspects of conflict intensity by various variables. The analysis is concluded by assessing welfare implications of selected conflict intensity scenarios.

Our framework allows separating impacts of conflict on consumer demand, marginal costs of marketing, wholesalers' conduct and market competitiveness, and the potential size of the market (e.g., Berry 1990). Under some circumstances, conflict provides an excellent exogenous mechanism by which supply behaviour can be identified. This decomposition into various components facilitates comprehending and quantifying economic consequences of violent conflict on food markets as well as informing relief missions carried out by local or international organizations. The quantification of various elements of conflict influence may enhance the efficacy of such missions by guiding efforts to alleviate the aspects of economic live of civilians most affected. For example, if market logistics are found to be most severely impeded, then aid policies can be tailored to focus on subsiding transportation costs or arranging UN backed transportation. But if the main consequence of conflict is found to be non-competitive conduct of traders, then policies such as temporal price caps may be a more suitable choice for relief.

The paper is organized as follows. Section 2 provides a concise review of the current literature studying economic effects of conflict. Section 3 highlights key aspects of the institutional background of the Israeli-Palestinian conflict and the induced fragmentation of economic space. Section 4 presents core aspects of the empirical framework while section 5 summarizes the datasets analysed. Section 6 presents the estimation and simulation results. Section 7 concludes and discusses extensions of the paper. This main text presents key aspects in order to hold the analysis concise. Comprehensive ancillary information for each of its sections - including detailed results of economic tests and elaborated argumentations - is provided in the Electronic Supplementary Material.

\section{Literature review}

Markets of many commodities have been studied using a discrete-choice framework with product differentiation based on a random utility (e.g., Berry et al. 1995; Verboven 1996). This method has increasingly been applied to processed food commodities (e.g., Nevo 2001), but to the best of our knowledge, this paper is a first attempt to employ this methodology to study fresh food markets in the context of violent political conflict in developing economies.

Arias et al. (2019) examined the effects of conflict on agricultural activities of farmers in Columbia. Rockmore (2015) studied how livestock portfolio and the choice of crops are affected by conflict in Uganda. In both cases it was reported that the risk of violence diverted farmers' decisions towards low-return activities. Focusing on the 2014 Gaza conflict, Brück et al. (2019) found that households' food security was not directly affected by the conflict but households' resilience capacity deteriorated. As more micro-level data such as in these studies becomes available, Martin-Shields and Stojetz (2019) provide a detailed analysis on the sources of and remedies for endogeneity in the empirical analysis of the relationship between food security and conflict.

Violent political conflict such as (civil) war or terrorism have been found to create negative economic effects (Murdoch and Sandler 2004, Abadie and Gardeazabal 2008, Cerra and Saxena 2008, Douarin et al. 2012, and others). For example, Abadie and Gardeazabal (2003) study the economic implications of political conflict in the Basque region of Spain. They find that terrorism reduces the per capita GDP in the Basque region relative to neighbouring regions. Ali and Lin (2010) find that civil wars significantly raise the average cost of food.

One specific conflict to which the economic literature has devoted much attention is the one between Israel and the Palestinians. Its economic effects have been studied by Fielding (2003); Eckstein and Tsiddon (2004); Zussman and Zussman (2006); Berrebi and Klor (2006); Ihle and Rubin (2013), and others. For example, Benmelech et al. (2010) estimate the macro-economic effect of Palestinian suicide 
attacks against Israeli targets on the Palestinian economy. They find that suicide attacks cause a significant increase in unemployment rates and a significant decrease in wages, as well as a decrease in the number of Palestinian workers employed in Israel. Ihle and Rubin (2013) study the microeconomic effects of movement restrictions on price dynamics of bilateral fruit and vegetable trade between Israel and the Palestinian Authority. They find that such restrictions increase the volatility of food prices and thus harm welfare.

Recent literature on the effects of violent conflict on preferences indicates that it has profound impact on shaping preferences and behaviour. This yields significant implications for recovery and economic development as preferences determine levels of consumption, saving and investment. Callen et al. (2014) investigate the relationship between conflict and risk preferences in Afghanistan. They show that individuals exposed to violence exhibit increased preference for certainty. The intensity of violent events is found to be positively correlated to the degree of risk aversion. Cecchi et al. (2016) show that exposure to conflict reduces risk aversion and increases altruism resulting in increased in-group cooperation as well as out-group antagonism. In the context of the Israeli-Palestinian conflict, Gould and Klor (2010) study the effects of terror attacks on the preferences of the Israeli electorate while Shayo and Zussman (2011) study the effects of conflict on judicial in-group bias.

\section{Institutional background}

In order to understand the challenges of the empirical analysis, we now elaborate on institutional aspects of the IsraeliPalestinian conflict (for a comprehensive overview, see Tinnes 2014 and Tinnes 2018). Hebron is a city with a significant history of violent incidents caused by the IsraeliPalestinian conflict (Clarke 2000). Its inhabitants have been strongly affected by escalations of political violence in recent decades. The city hosts the largest wholesale market in the West Bank serving about 550,000 residents (PCBS 2013). The entire market consists of some 50 individual wholesale trader shops which trade about 100 types of fruits and vegetables in total. Few of these goods are locally grown due to the arid environment, most of them are brought there from the Jordan valley in the Northern West Bank or imported from Israel, Jordan or other countries (WFP 2009, p. 44).

Households in Hebron spend the highest income shares on food in comparison to all Palestinian cities. In 2011, the average household in Hebron spent on average 39\% of total monthly expenditures on food while the Palestinian average amounted only to 33\% (PCBS 2012). While Palestinian households of at most 3 members spend on average $35 \%$ of their expenditures on food, this share rises to more than $43 \%$ for households with more than 10 members (PCBS 2012).
Similarly, expenditures on fruit and vegetables account for $7.1 \%$ of household expenditures (PCBS 2012).

As households' own food production is among the lowest in the Palestinian areas, they heavily depend on food purchases. Consequently, food price increases are of substantial importance for households in Hebron due to households' high economic vulnerability as food price shocks might yield in severe expenditure shocks. As they also spend relatively larger expenditure shares on food, livelihoods of the residents of this region are extremely sensitive to the development of the conflict.

In the Palestinian context apples are not considered a luxury food but play the most important role in household expenditures for fresh fruit. FAO (2005, p.3 and p. 17) finds that the dietary energy supply in the Palestinian Authority is mainly met on the basis of fruit and vegetables (703 g/day) and cereals (364 g/day). The monthly consumption of apples of the average Palestinian household amounts to $5 \mathrm{~kg}$ which corresponds to about one third of the monthly quantity of bread consumed (17.6 kg, PCBS 2011a, Table 3.1). The average monthly household expenditures calculated based on PCBS (2011a, Table 3.1) and PCBS (2011b, issue 2010, Table 9) are 27.5 NIS for apples, 22.9 NIS for bananas and 13 NIS for water melons. Thus, monthly expenditures for apples account in the Palestinian context for about $40 \%$ of the expenditures for bread. This evidence indicates the relevance of apples for food expenditures and thus the economic access to food (EC-FAO 2008) of the civilian population that is living subject to the conflict. As apple supply depends heavily on imports from Israel, trade flows but also access to market places are potentially highly challenged by conflict escalations (WFP 2009).

Escalations of violence have been reported to lead to temporary fragmentation of economic space in the West Bank and Gaza (Akkaya et al. 2008; OCHAoPt 2011; UNCTAD 2014). This fragmentation is caused by movement between and within cities being temporarily restricted by the attempts of the Israel Defence Forces (IDF) to control the situation (ECFAO 2007). Conflict-related restrictions on human movement or frontlines trench large cities or cut them off from their surrounding regions (WFP 2009; p. 17; OCHAoPt 2011, p. 2; OCHAoPt 2017). Road gates will be closed, temporary checkpoints will be erected, and curfews will be imposed. These measures, together with the presence of armed and fighting forces in and around large cities, will considerably suppress economic activity for a number of days so that the economic size of the market which equals in peace times the entire city including its surroundings is likely to be temporarily split off. Both, the political science as well as the economic literature agree that conflict incidences and intensities in the context of the Israeli-Palestinian conflict are exogenous to food prices as the cause of this conflict is the struggle for political and geographic control. 
Violent political conflict in such a context can thus impact consumer and trader behaviour in several ways. Conflict creates economic costs, uncertainty and disincentives for economic agents (Blattman and Miguel 2010). Food trade is a process involving several stages and is being carried out across geographic space. Thus, food supply and demand may become heavily impaired by conflict and markets can become fragmented (Woertz 2017; Veninga and Ihle 2018). Front lines through cities, curfews and movement restrictions may prevent farmers, traders and consumers to reach their areas of economic activity and to do business. Conflict might change purchase decisions and preferences (Callen et al. 2014) as well as marginal costs of marketing (WFP 2009).

\section{Modelling demand and pricing under violent conflict}

For being able to decompose economic consequences of violent conflict, we modify the logit demand model of Berry (1994) to explicitly account for the effects on demand, marginal costs, market competitiveness and potential market size. We implement this modified framework to model the transactions of apple varieties traded in the wholesale fruit and vegetable market of Hebron. We focus on sales of wholesalers to their clients, who can be either retailers or consumers. In our study, an observation consists of the aggregate daily transactions per apple variety, that is, total daily sales and the daily average price of apple variety $j \epsilon\{1, \ldots, V\}$. The number of wholesale traders at the Hebron fruit and vegetables market is very limited. Trader shops are spatially very closely located to each other; thus, traders are plausibly assumed to be price setters. Abramzon (2017), Dobers et al. (2018) and WFP (2009, pp. 43-45) document actually existing oligopolistic market structures. Thus, traders are plausibly assumed to maximize their short-run profits given the prices of other traders in the market. This suggests that prices follow a Nash-Bertrand equilibrium pricing game that results in an oligopolistic pricing rule (e.g., Verboven 1996; Fershtman and Gandal 1998).

Marginal costs are modelled as linear functions of observable characteristics of each variety and cost indicator variables $W_{j t}$, among them input prices, as well as unobservable cost characteristics $\omega_{j t}$. As for demand, marginal costs of variety $j$ on day $t$ can be affected by a set of conflict variables $C_{t}$ as well. Therefore, $\omega_{j t}$ may also consist of unobservable conflictrelated cost attributes. This yields the following estimable pricing equation (for the detailed derivations, see the Electronic Supplementary Material):

$P_{j t}=W_{j t} \gamma+C_{t} \eta+\frac{1}{\alpha\left(1-S_{j t}\right)}+\omega_{j t}$ where $\gamma$ and $\eta$ are coefficients and $1 / \alpha\left(1-S_{j t}\right)$ is the mark-up term to be estimated.

We modify the estimable demand equation $\ln \left(\frac{S_{j t}}{S_{0 t}}\right)=X_{j t} \beta$ $-\alpha P_{j t}+Z_{t} \lambda+\xi_{j t}$ (A3.1 derived in section 4 of the Electronic Supplementary Material).

and (1.1) to account for potential market fragmentation. Note that $S_{0 t}=\frac{M_{t^{-}} \sum_{j \in V} q_{j t}}{M_{t}}=1-\frac{\sum_{j \in V} q_{j t}}{M_{t}}$ is the market share of the outside good, $j=0$, which is available for consumption instead of all apple varieties $j$ in the market. Substitute the definitions of the market share $S_{j t}$ of the $j$-th variety and $S_{0 t}$ into the demand Eq. (A3.1) to obtain

$\ln \left(\frac{S_{j t}}{S_{0 t}}\right)=\ln \left(\frac{q_{j t}}{M_{t}-\sum_{j \in V} q_{j t}}\right)=X_{j t} \beta-\alpha P_{j t}+Z_{t} \lambda+\xi_{j t}$

and rearrange to get

$\ln \left(q_{j t}\right)=\ln \left(M_{t}-\sum_{j \in V} q_{j t}\right)+X_{j t} \beta-\alpha P_{j t}+Z_{t} \lambda+\xi_{j t}$

To model the influence of conflict intensity on the potential market size, $M_{t}$ has to be multiplied by the term $\left(1+\mu D_{t}^{\text {conf }}\right)$ so that market size $M_{t}^{\text {conf }}=\left(1+\mu D_{t}^{\text {conf }}\right) M_{t}=M_{t}+\mu$ $D_{t}^{\text {conf }} M_{t}$ is obtained. Thus, the market size during conflict escalations $M_{t}^{\text {conf }}$ may be smaller or equal to the size of the market during peace times $M_{t}$. The dummy variable $D_{t}^{\text {conf }}$ signals the days on which conflict escalation in Hebron occurred. $M_{t}^{\text {conf }}$ affects demand elasticities as well as mark-ups and, thus, the market structure (for details see Table A.2 in the Electronic Supplementary Material). The coefficient $\mu$ measures the magnitude of this market fragmentation effect. In consequence, we obtain the following estimable system of demand and pricing equations:

$$
\begin{aligned}
& \ln \left(q_{j t}\right)= \ln \left(\mathrm{M}_{t}^{\text {conf }}-\sum_{j \in V} q_{j t}\right)+X_{j t} \beta-\alpha P_{j t}+Z_{t} \lambda \\
&+\xi_{j t} \quad \text { and } \\
& P_{j t}=W_{j t} \gamma+C_{t} \eta+\frac{1}{\alpha\left(1-\frac{q_{j t}}{M_{t}^{\text {conf }}}\right)}+\omega_{j t}, \quad M_{t}^{\text {conf }}
\end{aligned}
$$

We use instrumental variables methods to account for the potentially endogenous prices and quantities in our empirical model. 
Our main identification assumption is that conflict intensity possibly affects demand and pricing of food while not vice versa, that is, the conflict variables are exogenous in the demand Eq. (2) and in the pricing Eq. (3). There is ample consensus in the literature confirming from a macro as well as from a historical perspective that the Israeli-Palestinian conflict is about land and political control and not about food prices. Thus, the intensity of this particular conflict is plausibly not affected by food price levels; or in other words, a deviation of the price or the quantity of a specific apple variety from their means does not affect the variables quantifying conflict intensity.

This assumption may not hold for other conflicts in which political conflict is plausibly caused or fuelled by the dissatisfaction about food expenses. The literature has found empirical evidence that causality between food prices and intensity of violent conflict in general may run in both directions (Martin-Shields and Stojetz 2019). However, there is ample consensus that the Israeli-Palestinian conflict belongs to that class of conflicts which are caused by fundamental political dissent about political control instead of dissatisfaction about people's food expenses.

Both the economics as well as the political science literature agree that dissatisfaction with food price does not play any role in causing conflict escalations in the context of this particular conflict. Bar-Tal (1990a, 1990b), Falah (1996) or Tessler (2009) elaborate on its reasons, history and dynamics from a political science perspective. Jaeger and Paserman (2008, p. 1592) directly assess the dynamic pattern of violence and find that Palestinians "deliberately choose to randomize the timing of their response to Israeli violence". The only causal relation they are able to robustly confirm is that Palestinian violence causes Israeli violence but not vice versa. Jaeger and Paserman (2006) establish that the Israeli response depends on which Palestinian group has committed violent acts first - again, food playing no role. Zussman and Zussman (2006, p. A194) suggest to interpret the Second Intifada "as a form of economic warfare" emphasizing the relevance of violence escalations for stock prices in Israel - again with no mention of any potential causal role of food prices.

Consequently, the extent to which our results are transferable to other political conflicts depends on their specific food expenditure and food marketing context. Our approach is transferable to the analysis of conflict contexts in which food prices are plausibly not affecting conflict intensity.

\section{Data}

We use a unique set of trade transactions at the Hebron wholesale fruit and vegetable market (HWM 2011, see ARIJ 2018 for institutional details). These consist of the daily average prices and total quantities of daily transactions of all apple varieties traded in the market. From qualitative interviews with Palestinian traders, we know the quality level and the origin of each variety considered. Our dataset consists of 3162 observations of aggregated daily transactions of 13 apple varieties. The observations cover the period between May 2007 and the end of September 2010, corresponding to 932 days. This is combined with a comprehensive set of variables quantifying complementary aspects of the intensity of conflict at daily level based on conflict-caused fatality counts collected and published by B'Tselem (2013a).

The varieties differ in a range of attributes based on characteristics, quality or consumer perception. The literature in horticultural sciences and consumer studies has established that the variety of an apple matters for consumers' purchases (e.g., Yue and Tong 2011). We follow Nevo (2001) in using one dummy variable for each of the apple varieties.

Based on a comprehensive dataset of daily conflict-caused fatality counts (B'Tselem 2013a) as well as closures within the West Bank, that is, effective restrictions on the movement of Palestinians (B'Tselem 2013b), we develop a number of indices measuring differing aspects of conflict (Table 1). The conflict variables are proxies for differing degrees of political violence potentially affecting local food markets in Hebron. We follow Rubin and Ihle (2017) for constructing and including variables into the analysis that quantify various complementary conflict intensity dimensions and time horizons.

Variables $\mathrm{C} 1$ to $\mathrm{C} 11$ in Table 1 measure conflict intensity on various geographical scales (for details see section 5 of the Electronic Supplementary Material). Conflict escalations in regions of differing distance and of more or less widespread character might affect economic agents in Hebron differently. We also consider the local conflict level in Hebron which is likely to have the most severe effects. In addition, conflict escalations in the West Bank and/or the Palestinian Authority in general are also likely to result in local effects in Hebron, as it is the economic centre of the West Bank. Lastly, if the conflict leads to fatalities in Israel, security measures on the West Bank and Gaza will be immediately enforced by the IDF. This is likely to also lead to local effects in Hebron food markets. The conflict variables constructed are mostly based on either fatality numbers of both Palestinians and Israelis, or fatality numbers of Palestinians in various geographical regions.

Table 2 presents the weighted-in-sales average prices and the average daily apple sales on days of conflict and without conflict - conflict being defined by variable $\mathrm{C} 13$. The daily total quantity of apples traded is reduced by $25 \%$ during days of conflict indicating that conflict suppresses economic activity. This finding strongly motivates the econometric analysis for identifying whether this effect was caused by a reduction in supply or a reduction in demand or both. 
Table 1 Summary statistics of the conflict variables

\begin{tabular}{|c|c|c|c|c|}
\hline Variable & Mean & Min & Max & Std. dev. \\
\hline $\mathrm{C} 1$ : Dummy for at least 30 fatalities in the last 30 days & 0.31 & 0 & 1 & 0.46 \\
\hline C2: Dummy for any fatalities in the last 3 days & 0.49 & 0 & 1 & 0.5 \\
\hline C3: Dummy for an exceptionally deadly day in the Palestinian Authority & 0.03 & 0 & 1 & 0.16 \\
\hline C4: Dummy for any fatalities in Israel in the last 7 days & 0.04 & 0 & 1 & 0.21 \\
\hline C5: Dummy for any fatalities in the West Bank in the last 3 days & 0.22 & 0 & 1 & 0.42 \\
\hline C6: Interaction of dummy for imported apples and $\mathrm{C} 1$ & 0.18 & 0 & 1 & 0.39 \\
\hline C7: Interaction of dummy for imported apples and $\mathrm{C} 2$ & 0.28 & 0 & 1 & 0.45 \\
\hline C8: Interaction of dummy for imported apples and C3 & 0.02 & 0 & 1 & 0.13 \\
\hline C9: Interaction of dummy for imported apples and C4 & 0.02 & 0 & 1 & 0.14 \\
\hline C10: Interaction of dummy for imported apples and C5 & 0.13 & 0 & 1 & 0.34 \\
\hline C11: Dummy for any fatalities in Hebron in the last 7 days & 0.08 & 0 & 1 & 0.26 \\
\hline C12: Dummy for comprehensive closure & 0.15 & 0 & 1 & 0.36 \\
\hline C13: Dummy for local conflict in Hebron $\left(D_{t}^{\text {conf }}\right)$ & 0.09 & 0 & 1 & 0.28 \\
\hline
\end{tabular}

Source: Authors' calculations based on B'Tselem (2013a, 2013b). We follow the approach suggested by Rubin and Ihle (2017) for the generation and selection of these variables. Table A.3 in the Electronic Supplementary Material contains the summary statistics of the remaining independent variables which are not related to conflict

\section{Estimation and simulation}

Table 2 Price and quantity: conflict vs. non-conflict and local vs. imported varieties

\begin{tabular}{lll}
\hline & Price $^{\mathrm{a}}(\mathrm{NIS} / \mathrm{kg})$ & Quantity (kg/day) \\
\hline All periods & & \\
$\quad$ All varieties & 2.52 & 9105 \\
Imported varieties & 2.97 & 4145 \\
Locally produced varieties & 2.14 & 4960 \\
Conflict periods & & \\
All varieties & 2.39 & 6946 \\
Imported varieties & 3.02 & 3104 \\
Locally produced varieties & 1.89 & 3842 \\
Non-conflict periods & & \\
All varieties & 2.53 & 9356 \\
Imported varieties & 2.97 & 4266 \\
Locally produced varieties & 2.17 & 5089 \\
Percentage change due to conflict $(\%)^{\mathrm{c}}$ & \\
All varieties & $-5.51^{* * *}$ & $-25.76^{* *}$ \\
Imported varieties & 1.74 & $-27.26^{*}$ \\
Locally produced varieties & $-12.95^{* * *}$ & $-24.50^{* *}$ \\
\hline
\end{tabular}

Notes: $* * *, * *, *$ denote significance at the $0.01,0.05$ and 0.1 levels, respectively

${ }^{a}$ Average price is weighted by sales

${ }^{\mathrm{b}}$ The effect of the conflict was calculated according to variable $\mathrm{C} 13$

${ }^{\mathrm{c}}$ Significance was calculated using a two-tailed t-test for difference between two means

Price and quantity effects of conflict defined by alternative variables are robust, see for details Table A.5 and Table A.6 in the Electronic Supplementary Material

Source: Authors
We apply the generalized method of moments to simultaneously estimate the system of demand Eqs. (2) and pricing Eqs. (3) for each variety. The variables on the left hand side are the natural $\log$ of the quantity traded in day $t$ and its price, respectively. We account for non-linearity and cross-equation restrictions associated with the parameters $\alpha$ and $\mu$ as well as for possible correlations between the errors $\xi_{j t}$ and $\omega_{j t}$ in both equations.

In the demand Eq. (2), the price as well as quantities appearing on the right-hand side are endogenous. In the pricing Eq. (3), quantities inside the mark-up term are endogenous. We use dummy variables for months as well as index variables for week numbers, squared week numbers and the number of other apple varieties traded in the market on a given day to instrument the quantities of specific apple varieties. We use the prices of three apple varieties in the wholesale market in Tel Aviv to instrument the price of apple varieties traded in Hebron. As mentioned above, the consensus in the political science as well as in the economic literature about causes of the conflict suggests that conflict is exogenous as escalations of the IsraeliPalestinian conflict are not influenced by food prices (more details on the instruments used as well as assessments of their quality are presented in sections 6.3 and 6.4 of the Electronic Supplementary Material).

\subsection{Estimation results}

Table 3 to Table 5 report the estimation results of the demand Eq. (2) and the pricing Eq. (3), respectively. Table 3 shows the results for the non-conflict-related explanatory variables. As expected, the coefficient of the price $-\alpha$ is negative and 
Table 3 Estimates of the coefficients of non-conflict-related explanatory variables

\begin{tabular}{|c|c|c|}
\hline Variable $^{\mathrm{a}}$ & $\begin{array}{l}\text { Coefficient } \\
\text { in demand Eq. (2) }\end{array}$ & $\begin{array}{l}\text { Coefficient in pricing } \\
\text { Eq. (3) }\end{array}$ \\
\hline Price $(-\alpha)$ & $-1.210 * * *$ & $-1.210 * * *$ \\
\hline Year 2007 & $-0.405 * * *$ & $-0.199 * * *$ \\
\hline Year 2008 & $0.368 * * *$ & $-0.214 * *$ \\
\hline Year 2009 & $0.437 * * *$ & -0.006 \\
\hline Weekend & $0.602 * * *$ & $0.057 * * *$ \\
\hline Muslim holiday & $1.606^{* * *}$ & 0.066 \\
\hline Ramadan & $0.221 * * *$ & $0.177 * * *$ \\
\hline $\begin{array}{c}\text { Labour cost index } \\
\text { commerce WB }\end{array}$ & & $0.046^{* * *}$ \\
\hline $\begin{array}{l}\text { Transportation cost } \\
\text { index WB }\end{array}$ & & $0.012 * *$ \\
\hline $\begin{array}{l}\text { Communication cost } \\
\text { index WB }\end{array}$ & & $0.079 * * *$ \\
\hline $\begin{array}{l}\text { Mean apple price at Tel } \\
\text { Aviv }\end{array}$ & & $0.329 * * *$ \\
\hline $\begin{array}{l}\text { Daily transaction } \\
\text { frequency }\end{array}$ & & -0.006 \\
\hline No. of observations & 3162 & 3162 \\
\hline Pseudo $R^{2 \mathrm{~b}}$ & 0.10 & 0.55 \\
\hline
\end{tabular}

Notes: $* * *, * *, *$ denote significance at the $0.01,0.05$ and 0.1 levels, respectively

${ }^{a}$ Both the demand and pricing equations include variety dummy variables as well as conflict-related variables (see Table 5 for the results of the explanatory conflict-related variables)

${ }^{\mathrm{b}}$ Pseudo $R^{2}$ is the square of the correlation between the dependent variable's predicted and observed values

Source: Authors

significant being estimated as -1.21 . The higher the price, the lower the utility for the consumer and the lower the quantities purchased. One of the apple varieties is used as the reference variety while the reference year is 2010. Most of the control variables have a significant influence on demand as well as on marginal costs of marketing. Table 3 suggests that apple demand during weekends is higher than on other days. Muslim holidays and Ramadan have a strongly positive and significant demand effect which is consistent with the traditional food served by Palestinians during these holidays.

The variables of the pricing equation explain the marginal costs of apple marketing. The results in the third column of Table 3 show a convergence of marginal costs towards 2010 levels. In 2007 and 2008, marginal costs were significantly lower than in 2010. In 2009, the marginal marketing costs of apples did not significantly deviate from 2010 levels. The estimated coefficients of the weekend dummy indicate that marginal costs rise slightly $(0.06 \mathrm{NIS} / \mathrm{kg})$ but significantly relatively to the rest of the week. Muslim holidays, not including Ramadan, do not affect marginal costs. During Ramadan,
Table 4 Elasticities and mark-ups

\begin{tabular}{|c|c|c|c|}
\hline & $\begin{array}{l}\text { Own price } \\
\text { elasticity }^{\mathrm{a}}\end{array}$ & Mark-up $^{\mathrm{a}, \mathrm{d}}(\%)$ & $\begin{array}{l}\text { Mark-up }^{a} \\
\text { (NIS/kg) }\end{array}$ \\
\hline \multicolumn{4}{|l|}{ All periods } \\
\hline All varieties & 2.90 & 37.88 & 0.87 \\
\hline Imported varieties & 3.45 & 30.99 & 0.86 \\
\hline Locally produced varieties & 2.45 & 43.64 & 0.88 \\
\hline \multicolumn{4}{|l|}{ Conflict periods ${ }^{\mathrm{b}}$} \\
\hline All varieties & 2.74 & 41.59 & 0.87 \\
\hline Imported varieties & 3.46 & 30.82 & 0.88 \\
\hline Locally produced varieties & 2.16 & 50.29 & 0.87 \\
\hline \multicolumn{4}{|l|}{ Non-conflict periods ${ }^{\mathrm{b}}$} \\
\hline All varieties & 2.92 & 37.56 & 0.87 \\
\hline Imported varieties & 3.44 & 31.00 & 0.86 \\
\hline Locally produced varieties & 2.48 & 43.05 & 0.88 \\
\hline \multicolumn{4}{|c|}{ Percentage change due to $\operatorname{conflict}^{\mathrm{c}}(\%)$} \\
\hline All varieties & -6.0 & 10.7 & 0.3 \\
\hline Imported varieties & 0.4 & -0.6 & 1.4 \\
\hline Locally produced varieties & -12.6 & 16.8 & -0.6 \\
\hline
\end{tabular}

Notes: ${ }^{\text {a }}$ The average own price elasticities in absolute values and the average mark-ups are weighted by sales

${ }^{\mathrm{b}}$ Days of conflict are defined by the variable $\mathrm{C} 13$ taking the value 1 which is the conflict measurement quantifying the incidence of local conflict in the city of Hebron

${ }^{\mathrm{c}}$ This is the percentage change between the corresponding estimates during non-conflict periods and conflict periods

${ }^{\mathrm{d}}$ The percentage mark-up is calculated by dividing the mark-up in absolute terms by price

Source: Authors

marginal costs increase significantly by $0.18 \mathrm{NIS} / \mathrm{kg}$. As expected, the cost indices positively affect marginal costs.

We find that demand for each apple variety is elastic - a result of many substitutes in the market (Table 4). The own price elasticity of all apples varieties is 2.9 in absolute terms while it is slightly less elastic on days of conflict $(2.74$, conflict being defined by $\mathrm{C} 13$ taking the value 1). Demand for local apples is less elastic than demand for imported apples.

Table 4 also indicates that the own price elasticity of all varieties decreases by $6 \%$ between periods with conflict in comparison to periods without conflict. When this change is differentiated between imported and locally produced varieties, then a substantial contrast becomes visible. While the price elasticity of imported varieties barely changes $(0.4 \%)$, a distinct decline of almost $13 \%$ happens for locally produced varieties. Imported varieties have longer storability as Israeli growers and traders enjoy better access to input factors, capital and storage facilities. Therefore, Hebron consumers seem to prefer to purchase 
Table 5 Estimates of the coefficients of the conflict variables

\begin{tabular}{|c|c|c|}
\hline Variable & $\begin{array}{l}\text { Coefficient in } \\
\text { demand Eq. (2) }\end{array}$ & $\begin{array}{l}\text { Coefficient } \\
\text { inpricing Eq. (3) }\end{array}$ \\
\hline $\begin{array}{l}\text { C1: Dummy for at least } 30 \\
\text { fatalities in the last } 30 \text { days }\end{array}$ & 0.052 & \\
\hline $\begin{array}{l}\text { C2: Dummy for any fatalities } \\
\text { in the last } 3 \text { days }\end{array}$ & $0.162 * *$ & $0.062 * * *$ \\
\hline $\begin{array}{l}\text { C3: Dummy for an exceptionally } \\
\text { deadly day in the Palestinian } \\
\text { Authority }\end{array}$ & $0.360 *$ & \\
\hline $\begin{array}{l}\text { C4: Dummy for any fatalities in } \\
\text { Israel in the last } 7 \text { days }\end{array}$ & -0.103 & \\
\hline $\begin{array}{l}\text { C5: Dummy for any fatalities in } \\
\text { the West Bank in the last } 3 \text { days }\end{array}$ & $-0.209 * *$ & \\
\hline $\begin{array}{l}\text { C6: Interaction of dummy for } \\
\text { imported apples and } \mathrm{C} 1\end{array}$ & $0.568 * * *$ & \\
\hline $\begin{array}{l}\text { C7: Interaction of dummy for } \\
\text { imported apples and } \mathrm{C} 2\end{array}$ & 0.015 & \\
\hline $\begin{array}{l}\text { C8: Interaction of dummy for } \\
\text { imported apples and C3 }\end{array}$ & $-0.617 * *$ & \\
\hline $\begin{array}{l}\text { C9: Interaction of dummy for } \\
\text { imported apples and C4 }\end{array}$ & 0.166 & \\
\hline $\begin{array}{l}\text { C10: Interaction of dummy for } \\
\text { imported apples and C5 }\end{array}$ & 0.121 & \\
\hline $\begin{array}{l}\text { C11: Dummy for any fatalities in } \\
\text { Hebron in the last } 7 \text { days }\end{array}$ & & 0.055 \\
\hline $\begin{array}{l}\text { C12: Dummy for comprehensive } \\
\text { closure }\end{array}$ & & 0.023 \\
\hline $\begin{array}{l}\text { C13: Dummy for local conflict } \\
\text { in Hebron }(\mu)\end{array}$ & $-0.145 * *$ & $-0.145 * *$ \\
\hline
\end{tabular}

Notes: ***,**,* denote significance at the $0.01,0.05$ and 0.1 levels, respectively

Source: Authors

Israeli varieties in times of conflict. Hence, what we observe might be interpreted as temporarily lowered consumption levels of the local produce on the expense of keeping the level of the imported varieties stable.

Table 5 displays the estimates of the coefficients of the variables quantifying complementary aspects of conflict intensity. The estimated coefficient of the market size parameter $\mu$ of 0.145 is significant. This estimate suggests that escalations of violence that have local effects on the city of Hebron indeed reduce potential market size by a substantial magnitude of $14.5 \%$. Additional robustness checks show that the estimates of $\mu$ and $\alpha$ are robust throughout different measures of potential market size. Results are available from authors upon request. This finding confirms the qualitative evidence documented by OCHAoPt (2017) and other sources such as EC-FAO (2008) that violent conflict indeed may substantially fragment economic space.

In the demand equation, a number of determinants play a role. If there is an exceptional escalation of violence, then import demand for apples collapses in the short run (variable C8). However, in the middle run, demand for imported apples rises if some conflict took place in the last month (variable C6). If any fatalities for either conflict party in either region are observed in the prior three days, then demand rises slightly (variable $\mathrm{C} 2$ ) while demand shrinks if there are conflict escalations only in the West Bank (variable C5).

In the pricing equation, marginal costs are positively, albeit slightly impacted $(0.06 \mathrm{NIS} / \mathrm{kg})$ by the general level of conflict in the short run (variable $\mathrm{C} 2$ ). The positive effects on marginal costs due to local conflict in Hebron (variable C11) and to closure of the West Bank Barrier (variable $\mathrm{C} 12$ ) are not statistically significant.

Table 4 shows that the weighted-in-sales average mark-up of apples is $0.87 \mathrm{NIS} / \mathrm{kg}$. The exogenous variation in availability and variety of apples due to conflict did not shift the mark-up in NIS/kg as they barely change between conflict and non-conflict periods. During days of conflict, apple quantities $q_{j t}$ are reduced by $12.6 \%$. The percent mark-up during days of conflict is higher (Table 4) due to the reduction in own price elasticity. The average percentage mark-up of all varieties raises by almost $11 \%$ - which is mainly due to the substantial increase of $16.8 \%$ for locally produced varieties while the percentage mark-up of imported varieties virtually stays constant in both periods.

We preformed comprehensive robustness checks of these results such as estimating a nested logit version and a random coefficient version of the demand equation as well as alternative pricing rules such as collusion and strategic impact of the conflict (see section 6 of the Electronic Supplementary Material). This comprehensive examination of robustness shows that the estimation results reported are robust across all alternative specifications. Detailed results are available from the authors upon request. As part of this, we also examined whether model results are driven by the inclusion of conflict variables. We ran several specifications of the model and found that the results are stable (Table A.7 in the Supplementary Material). This is in line with Rubin and Ihle (2017) who show that it is possible to construct various conflict variables based on a common dataset that measure complementary aspects of conflict. We follow their approach for the generation and selection of the variables reported in Table 1 in order to avoid issues such as the one highlighted by Schrodt (2014).

\subsection{Simulation results}

Based on the estimated parameters, the system of demand and pricing Eqs. (2) and (3) of apple varieties makes up an 
equilibrium model enabling to estimate the welfare impacts of various scenarios depending on the intensity of the conflict (e.g., Fershtman and Gandal 1998; Tchetchik et al. 2008; Fleischer et al. 2018; Bar-Nahum et al. 2018, see section 6.2 of the Electronic Supplementary Material for a detailed explanation of this approach). We use observed prices, observed quantities and model covariates to derive a calibrated baseline market equilibrium of a representative day which is defined by the averages of the observed conflict variables in the sample. After an exogenous change in conflict intensity, the model searches for sets of $J$ variety prices and quantities that solve simultaneously the demand and pricing equilibrium equations. Exogenous to the equilibrium model is the conflict's intensity level. Based on that, we consider the following two scenarios for simulation which we compare to the baseline:

Scenario 1. High-intensity local conflict: this represents a scenario of a day in which local conflict has been observed to be of very high intensity. This is operationalized by letting the variable C13 equal the value one for all observations and using the average values of the other observed explanatory variables when $\mathrm{C} 13=1$.

Scenario 2. Low-intensity local conflict: this represents a scenario of a day in which local conflict has been observed to be of very low intensity. This is operationalized by letting the variable $\mathrm{C} 13$ equal the value zero for all observations and use the average values of the other observed explanatory variables when $\mathrm{C} 13=0$.

Table 6 Simulated changes on a daily basis

\begin{tabular}{lll}
\hline Change of & $\begin{array}{l}\text { High-intensity } \\
\text { local conflict }\end{array}$ & $\begin{array}{l}\text { Low-intensity } \\
\text { local conflict }\end{array}$ \\
\hline Price & $+1 \%$ & $-1 \%$ \\
Total quantity & $-15 \%$ & $+4 \%$ \\
Consumer surplus & & \\
$\quad$ In absolute terms & $-8352 \mathrm{NIS}$ & $+4487 \mathrm{NIS}$ \\
$\quad$ In percentage terms & $-13.3 \%$ & $+7.1 \%$ \\
Producer surplus & & \\
$\quad$ In absolute terms & $-3403 \mathrm{NIS}$ & $+1685 \mathrm{NIS}$ \\
$\quad$ In percentage terms & $-13.2 \%$ & $+6.6 \%$ \\
Welfare & & \\
In absolute terms & $-11,755 \mathrm{NIS}$ & $+6172 \mathrm{NIS}$ \\
In percentage terms & $-13.3 \%$ & $+7.0 \%$ \\
\hline
\end{tabular}

Note: ${ }^{a}$ The consumer surplus is calculated based on the formula for consumer surplus per consumer in the logit model $C S=\ln \left(\sum_{j=0}^{V} \mathrm{e}^{\delta_{j}}\right) / \alpha$

Source: Authors
Table 6 reports the simulated daily changes in the average price of all apples, the total traded quantity, consumer surplus, wholesalers' surplus, and welfare. Local conflict of high intensity creates a significant cost in terms of economic welfare, estimated at 11,755 NIS (3185 USD) per day corresponding to about $50 \%$ of the average daily revenue of apples in the Hebron wholesale market. Similarly, low intensity of local conflict creates a significant gain in economic welfare, estimated at 6172 NIS (1672 USD) per day corresponding to about $25 \%$ of the average daily revenue of apples in the Hebron wholesale market. Hence, the effect of suppressing demand appears to be more significant than the increase in marginal cost visible in the price changes. The sum of the welfare gains of both scenarios amounts to 18,000 NIS (4878 USD, 20\% welfare increase). This gives an estimate of the total welfare gain in apple wholesale trade for a change from high-intensity to low-intensity local conflict, aka peace dividend in the literature (e.g. Fershtman and Gandal 1998). This amount is of substantial magnitude as it accounts for $75 \%$ of the average daily revenue in apple wholesale trade in Hebron. The magnitude of this peace dividend would be emphasized by extrapolating it to the total daily revenue of fresh fruit and vegetable trade in the entire West Bank.

\section{Conclusions and discussion}

The current literature has mostly analysed economic effects of war, violent conflict, and terrorism (e.g., Benmelech et al. 2010) or conflict as a result of threatened food security (e.g., Koren and Bagozzi 2016) at the macro-level. Recently a limited number of studies have started to focus on the micro-economic effects of conflict on food markets. In this paper, we introduce an empirical framework that enables decomposing micro-economic effects of violent political conflict on food markets. The framework enables quantifying and isolating the magnitudes of transitory economic effects of conflict-caused escalations of violence on several aspects of food markets in conflict contexts where threats to food security are plausibly not affecting conflict incidence or intensity. This applies to violent conflicts which have some fundamental political disagreement at their core in contrast to food riots which are caused by threats to food security (scuh as the Arab Spring). Examples are the conflict between Israel and the Palestinians as well as the conflicts in Syria, Iraq, Libya or Afghanistan (see section 6.3 of the Electronic Supplementary Material for details).

We suggest the use of a structural equilibrium model for that aim. In particular, we suggest a differentiated goods oligopoly model which can be estimated with data typically available even in the context of conflict in developing countries. We complement this standard framework by tailoring the approach using several variables measuring complementary aspects of conflict intensity (as suggested, e.g., by Rubin and Thle 2017) and by allowing for variations in market size. This explicit consideration 
of political instability of physical and economic access to food is a crucial precondition for food security (EC-FAO 2008) which barely has received attention in the literature although economic fragmentation has been frequently reported to be one major implications of violent conflict as frontlines often fragment major cities. The extended framework we suggest is able to separately identify whether and to what extent conflict intensity affects market size. It decomposes effects of conflict into partial effects on marginal costs, food prices and market competitiveness by also allowing for assessing potential fragmentation of physical market access.

Combining daily data on the sales of apples - one major ingredient of Palestinian diet - in the Hebron wholesale market with daily measurements of conflict intensity, we find significant effects of conflict on apple marketing and demand. Demand for imported apples collapses on days of escalating conflict whereas it increases on days of moderate conflict. Market size as well as total daily apple consumption quantities are found to be substantially reduced during intensive conflict at local level. The simulation results indicate a considerable welfare loss in times of high-intensity conflict and a welfare gain resulting from conflict pacification. In an environment of lowintensity conflict compared with the situation of conflict of highest observed intensity, a total welfare gain of about $20 \%$ corresponding to almost 5000 USD per day - is realized.

Our results are useful for informing relief policies in a targeted way because they disentangle transitory microeconomic effects of violent political conflict on various aspects of food security. The effect of suppressing demand is found to be more significant than the increase in marginal costs. This is noteworthy to observe as availability is often conceptualized as representing the supply side of food security while access pertains to demand, our findings suggest that it is access in the given case that is more severely impeded by conflict. Our results suggest that it is important for relief policies to focus on alleviating effects of fragmentation of economic space, e.g., by negotiating humanitarian corridors within cities so that physical cut-offs from food supply are avoided.

The framework suggested based on a standard approach for estimating demand in differentiated product markets using market transactions data can be used as a feasible tool for empirically assessing micro-economic effects of violent political conflict on other food commodities or on aggregated local, regional or national food markets. The framework we suggest fits a wide range of similar contexts in which developing countries suffer from political destabilization and understanding micro-economic consequences of conflict escalations on market equilibrium and stakeholders' welfare is crucial. Data requirements are fair and not too demanding given the challenges of data collection in conflict contexts in developing economies - for making the analysis feasible in many relevant contexts. For using this approach for another particular conflict, its institutional structure is decisive as it determines the plausibility of the main identification assumption concerning the exogeneity of food prices to conflict. Otherwise, it is necessary to account for potential endogeneity as discussed, e.g., in Martin-Shields and Stojetz (2019). This analysis highlights the benefits of food price and food trade monitoring (Baltussen et al. 2019) for being able to monitor short-run food security in environments of political destabilization.

Future research - motivated by the widespread occurrence of violent political conflict throughout the Middle East, North Africa or Sub-Saharan Africa (World Bank 2011) - might evolve into several directions. It could deepen and extend the understanding of economic effects of violent political conflict on food markets, food security, actual nutritional patterns and nutrition vulnerability at the micro-level. Such improved understanding could be achieved by gathering more quantitative measurements, but also via qualitative socio-economic research which could contribute to understand the underlying mechanisms leading to insights as, e.g., reported in Table 5. Straightforward extensions might focus on providing comparative analyses of pricing and demand for a number of fresh food commodities in more than one market or more than one conflict. An analysis of conflict effects on processed and storable foods for which supply is more constant due to potential stockpiling, would be insightful too. We thank an anonymous reviewer for pointing out that analysing the extent to which food prices act as threat- or anger-multipliers in violent political conflict would contribute to improving the understanding of conflict dynamics. Lastly, further research could also assess nutritional impacts of conflict when demand effects of various commodities are translated into nutritional intake. In this way, a comparison of impacts across food commodities of various expenditure shares or nutritional importance can be achieved.

Acknowledgements The authors acknowledge the generous support of the Deutsche Forschungsgemeinschaft (DFG) for the research project "The Economic Integration of Agriculture in Israel and Palestine" (grant number: CR 95/7-1). The authors also gratefully acknowledge the very constructive help for data gathering provided by Wassim Ghantous, Noam Preiss, Noa Tal and Suhair Abdi from B'Tselem.

\section{Compliance with ethical standards}

Conflict of interest The authors declare that they have no conflict of interest.

Open Access This article is licensed under a Creative Commons Attribution 4.0 International License, which permits use, sharing, adaptation, distribution and reproduction in any medium or format, as long as you give appropriate credit to the original author(s) and the source, provide a link to the Creative Commons licence, and indicate if changes were made. The images or other third party material in this article are included in the article's Creative Commons licence, unless indicated otherwise in a credit line to the material. If material is not included in the article's Creative Commons licence and your intended use is not 
permitted by statutory regulation or exceeds the permitted use, you will need to obtain permission directly from the copyright holder. To view a copy of this licence, visit http://creativecommons.org/licenses/by/4.0/.

\section{References}

Abadie, A., \& Gardeazabal, J. (2003). The economic costs of conflict: A case study of the Basque Country. American Economic Review, 93(1), 113-132.

Abadie, A., \& Gardeazabal, J. (2008). Terrorism and the world economy. European Economic Review, 52(1), 1-27.

Abramzon, Y. (2017). Profitability in the marketing chain of fresh vegetables and fruit in 2015. Report prepared for the joint price committee for the Ministry of Finance and the Ministry of Agriculture (Hebrew). http://www.moag.gov.il/yhidotmisrad/research economy_strategy/Documents/Interval_marketing_fruits_and_ vegetables.pdf. Accessed October 2019.

Aitchison, J., \& Brown, J. A. C. (1954). A synthesis of Engel curve theory. The Review of Economic Studies, 22(1), 35-46.

Akkaya, S., Fiess, N., Kaminski, B. \& Raballand, G. (2008). Economics of Policy-Induced Fragmentation: The Costs of Closures Regime to West Bank and Gaza. World Bank Middle East and North Africa, working paper no. 50 .

Ali, H. E., \& Lin, E. S. (2010). Wars, food cost and countervailing policies: A panel data approach. Food Policy, 35(5), 378-390.

Arias, M. A., Ibáñez, A. M., \& Zambrano, A. (2019). Agricultural production amid conflict: Separating the effects of conflict into shocks and uncertainty. World Development, 119, 165-184.

ARIJ (2018). Central wholesale Markets in the West Bank - study summary. The Applied Research Institute - Jerusalem/ Society. http:// www.arij.org/component/content/article/210-publications/foodmarket-assessments/baseline-surveys/670-central-wholesalemarkets-in-the-west-bank.html. Accessed August 2018.

B'Tselem (2013a). Statistics. http://old.btselem.org/statistics/english/ Casualties.asp. Current url: https://www.btselem.org/statistics. Accessed January 2013.

B'Tselem (2013b). Figures on comprehensive closure days. http://www. btselem.org/freedom_of_movement/siege_figures. Accessed March 2013.

Baltussen, W., Drabik, D., Dries, L., Galen van M., Gardebroek, C., Ihle, R., Logatcheva, K. \& Oosterkamp, E. (2019). Monitoring of prices and margins in EU food supply chains. Luxembourg. https://doi.org/ $10.2760 / 197814$.

Bar-Nahum, Z., Finkelshtain, I. \& Kan, I. (2018). On the effectiveness of price-ceiling regulations: The case of fluid milk market in Israel. Discussion Paper no. 2.18, Center for Agricultural Economic Research.

Bar-Tal, D. (1990a). Causes and consequences of Delegitimization: Models of conflict and ethnocentrism. Journal of Social Issues, 46(1), 65-81.

Bar-Tal, D. (1990b). Israeli-Palestinian conflict: A cognitive analysis. International Journal of Intercultural Relations, 14(1), 7-29.

Benmelech, E., Berrebi, C., \& Klor, E. F. (2010). The economic cost of harboring terrorism. Journal of Conflict Resolution, 54(2), 331-353.

Berrebi, C., \& Klor, E. F. (2006). On terrorism and electoral outcomes: Theory and evidence from the Israeli-Palestinian conflict. Journal of Conflict Resolution, 50(6), 899-925.

Berry, S. T. (1990). Airport presence as product differentiation. The American Economic Review, 80(20), 394-399.

Berry, S. T. (1994). Estimating discrete-choice models of product differentiation. The Rand Journal of Economics, 25(2), 242-262.
Berry, S. T., Levinsohn, J., \& Pakes, A. (1995). Automobile prices in market equilibrium. Econometrica: Journal of the Econometric Society, 63(4), 841-890.

Blattman, C., \& Miguel, E. (2010). Civil war. Journal of Economic Literature, 48(1), 3-57.

Brück, T., d'Errico, M., \& Pietrelli, R. (2019). The effects of violent conflict on household resilience and food security: Evidence from the 2014 Gaza conflict. World Development, 119, 203-223.

Callen, M., Isaqzadeh, M., Long, J. D., \& Sprenger, C. (2014). Violence and risk preference: Experimental evidence from Afghanistan. American Economic Review, 104(1), 123-148.

Cecchi, F., Leuveld, K., \& Voors, M. (2016). Conflict exposure and competitiveness: Experimental evidence from the football field in Sierra Leone. Economic Development and Cultural Change, 64(3), 405-435.

Cerra, V., \& Saxena, S. C. (2008). Growth dynamics: The myth of economic recovery. American Economic Review, 98(1), 439-457.

Clarke, R. (2000). Self-presentation in a contested city: Palestinian and Israeli political tourism in Hebron. Anthropology Today, 16(5), 12-18.

D'Souza, A., \& Jolliffe, D. (2013). Conflict, food price shocks, and food insecurity: The experience of afghan households. Food Policy, 42, $32-47$.

Dobers, G. M., Ihle, R., Kachel, Y., \& Liebe, U. (2018). Economic integration in the Middle East: Israeli-Palestinian fresh food trade. Israel Affairs, 24(3), 421-441.

Douarin, E., Litchfield, J., \& Sabates-Wheeler, R. (2012). War legacies, welfare and livelihoods in rural areas: The case of Kosovo. Journal of Agricultural Economics, 63(1), 201-222.

EC-FAO (2007). Strengthening Resilience: Food Insecurity and Local Responses to Fragmentation of the West Bank. EC-FAO Food Security Information of Action Programme. European Commission/ FAO, report.

EC-FAO (2008). An Introduction to the Basic Concepts of Food Security. Policy Brief, EC-FAO Food Security Programme. European Commission/ FAO, report.

Eckstein, Z., \& Tsiddon, D. (2004). Macroeconomic consequences of terror: Theory and the case of Israel. Journal of Monetary Economics, 51(5), 971-1002.

Falah, G. (1996). The 1948 Israeli-Palestinian war and its aftermath: The transformation and De-signification of Palestine's cultural landscape. Annals of the Association of American Geographers, 86(2), 256-285.

FAO (2005). Nutrition Country Profile Palestine, FAO, country report. http://www.fao.org/3/aq043e/aq043e.pdf. Accessed July 2017.

Fershtman, C., \& Gandal, N. (1998). The effect of the Arab boycott on Israel: The automobile market. The Rand Journal of Economics, 29(1), 193-214.

Fielding, D. (2003). Modelling political instability and economic performance: Israeli investment during the intifada. Economica, 70(277), 159-186.

Fleischer, A., Tchetchik, A., Bar-Nahum, Z., \& Talev, E. (2018). Is agriculture important to agritourism? The agritourism attraction market in Israel. European Review of Agricultural Economics, 45(2), 273-296.

Gould, E. D., \& Klor, E. F. (2010). Does terrorism work? The Quarterly Journal of Economics, 125(4), 1459-1510.

HWM. (2011). Hebron fruits and vegetables wholesale market. Hebron, Palestinian Authority: Price records.

Ihle, R., \& Rubin, O. D. (2013). Consequences of unintended food policies: Food price dynamics subject to the Israeli-Palestinian conflict. Food Policy, 42, 96-105.

Jaeger, D. A., \& Paserman, M. D. (2006). Israel, the Palestinian factions, and the cycle of violence. American Economic Review, 96(2), 45-49.

Jaeger, D. A., \& Paserman, M. D. (2008). The cycle of violence? An empirical analysis of fatalities in the Palestinian-Israeli conflict. American Economic Review, 98(4), 1591-1604. 
Koren, O., \& Bagozzi, B. E. (2016). From global to local, food insecurity is associated with contemporary armed conflicts. Food Security, 8(5), 999-1010.

Martin-Shields, C. P., \& Stojetz, W. (2019). Food security and conflict: Empirical challenges and future opportunities for research and policy making on food security and conflict. World Development, 119, 150-164.

Microcon (2018). Micro Conflict - A micro level analysis of violent conflict, Funded by EU-FP6. http://www.microconflict.eu. Accessed July 2018.

Murdoch, J. C., \& Sandler, T. (2004). Civil wars and economic growth: Spatial dispersion. American Journal of Political Science, 48(1), $138-151$.

Nevo, A. (2001). Measuring market power in the ready-to-eat cereal industry. Econometrica, 69(2), 307-342.

OCHAoPt (2011). West Bank Movement and Access Update, August 2011. United Nations Office for the Coordination of Humanitarian Affairs occupied Palestinian territory. East Jerusalem, report.

OCHAoPt (2017). West Bank Movement and Access Update (various issues). United Nations Office for the Coordination of Humanitarian Affairs occupied Palestinian territory. East Jerusalem. https://www.ochaopt. org/reports. Accessed February 2017.

PCBS (2011a). The Palestinian expenditure and consumption survey 2010, Palestinian Central Bureau of Statistics, Ramallah.

PCBS. (2011b). Price and Price Indices: Annual Bulletin, issues 2007 to 2010, tables 2 and 6. Ramallah: Palestinian Central Bureau of Statistics.

PCBS. (2012). Palestinian expenditure and consumption survey 2011: Living standards in the Palestinian territory expenditure, consumption, poverty, 2011. Ramallah: Palestinian Central Bureau of Statistics.

PCBS (2013). Guide to Palestinian statistics a - Z, Palestinian Central Bureau of Statistics, Ramallah. http://www.pcbs.gov.ps/site/lang en/507/default.aspx. Accessed March 2013.

Rockmore, M. (2015). Conflict and agricultural portfolios: Evidence from northern Uganda. Working Paper.

Rubin, O. D., \& Ihle, R. (2017). Measuring temporal dimensions of the intensity of violent political conflict. Social Indicators Research, 132(2), 621-642.

Schrodt, P. A. (2014). Seven deadly sins of contemporary quantitative political analysis. Journal of Peace Research, 51(2), 287-300.

Seale, J. L., Regmi, A. \& Bernstein, J. (2003). International evidence on food consumption patterns. Washington, DC: Economic Research Service, US Department of Agriculture.

Shayo, M., \& Zussman, A. (2011). Judicial ingroup bias in the shadow of terrorism. The Quarterly Journal of Economics, 126(3), 1447-1484.

Tchetchik, A., Fleischer, A., \& Finkelshtain, I. (2008). Differentiation and synergies in rural tourism: Estimation and simulation of the Israeli market. American Journal of Agricultural Economics, 90(2), 553570

Tessler, M. (2009). A history of the Israeli-Palestinian conflict. Second edition. Bloomington: Indiana University Press.

Tinnes, J. (2014). Bibliography: Israeli-Palestinian conflict (part 1). Perspectives on Terrorism, 8(5), 84-116.

Tinnes, J. (2018). Bibliography: Israeli-Palestinian conflict (part 2). Perspectives on Terrorism, 12(1), 152-185.

UNCTAD (2014). Trade facilitation in the occupied Palestinian territory: Restrictions and limitations. UNCTAD/GDS/APP/2014/1, United Nations conference on trade and development, New York and Geneva, USA and Switzerland.

Veninga, W., \& Ihle, R. (2018). Import vulnerability in the Middle East: Effects of the Arab spring on Egyptian wheat trade. Food security, 10(1), 183-194.

Verboven, F. (1996). International price discrimination in the European car market. The Rand Journal of Economics, 27(2), 240-268.
WFP (2009). The Impact of Closure and High Food Prices on Performance of Imported Staple Foods and Vegetable and Fruits Market in the oPt. United Nations world food Programme, Report, Rome, Italy.

Woertz, E. (2017). Food security in Iraq: Results from quantitative and qualitative surveys. Food Security, 9(3), 511-522.

World Bank (2011). World development report 2011: Conflict, security, and development. World Bank.

Yue, C., \& Tong, C. (2011). Consumer preferences and willingness to pay for existing and new apple varieties: Evidence from apple tasting choice experiments. HortTechnology, 21(3), 376-383.

Zussman, A., \& Zussman, N. (2006). Assassinations: Evaluating the effectiveness of an Israeli counterterrorism policy using stock market data. Journal of Economic Perspectives, 20(2), 193-206.

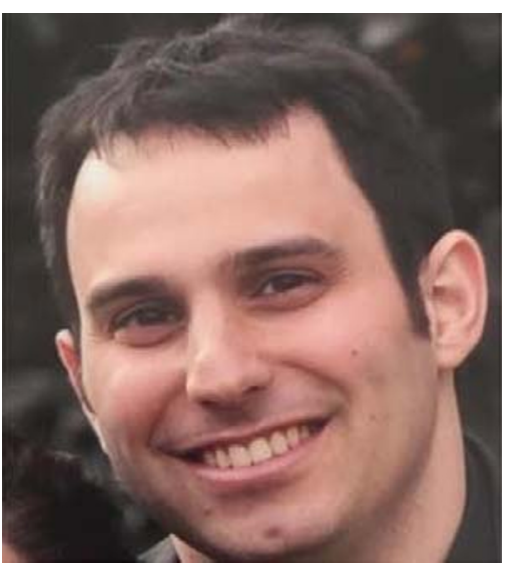

Ziv Bar-Nahum is research economist in the R e s e a c h, Economy, and Strategy Division at the Ministry of Agriculture and Rural Development, Israel, and lecturer in the Department of Environ m e t a 1 Economics and Management at the Hebrew University of Jerusalem. He holds $\mathrm{MSc}$ and $\mathrm{PhD}$ in agricultural economics both from the Hebrew University of Jerusalem. His research interests include empirical industrial organisation of food markets as well as economic evaluation of regulations, public policies and political processes in agricultural markets.

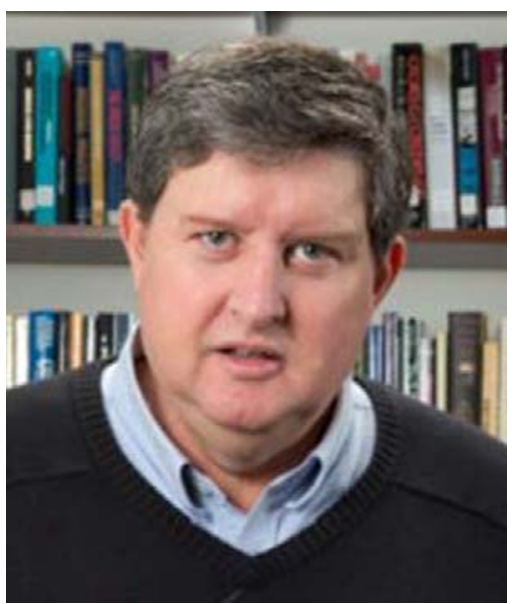

Israel Finkelshtain is associate professor in the Department of Environmental Economics and Management at the Hebrew University of Jerusalem. He holds an MSc in agricultural economics and management from the Hebrew University of Jerusalem and a $\mathrm{PhD}$ in agricultural and resource economics from the University of California, Berkeley. His research interests include sectoral structure of agricultural markets, political economy of farm policy and environmental regulations, agricultural risk management, and measurement of technological changes. 


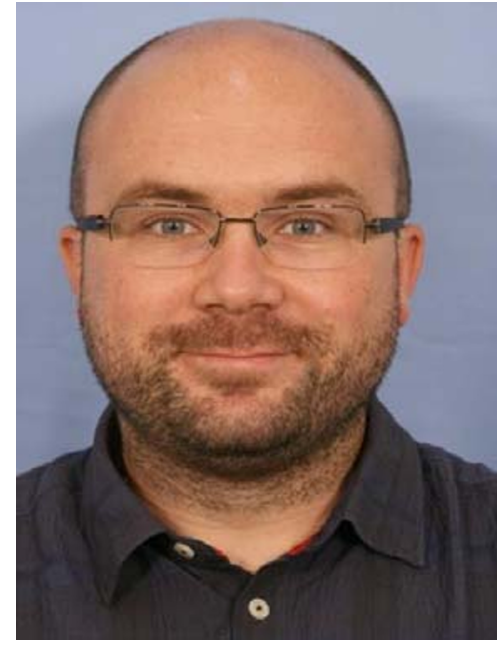

in the Middle East and Northern Africa (MENA).
Rico Ihle is assistant professor in the Agricultural Economics and Rural Policy Group of Wageningen University, The Netherlands. He holds an MSc and a PhD in agricultural economics from Georg-AugustUniversität Göttingen, Germany. His research interests include the analysis of prices of agricultural and food products, economic aspects of violent political conflict, the evaluation of the effects of public policies on food markets as well as the analysis of food markets

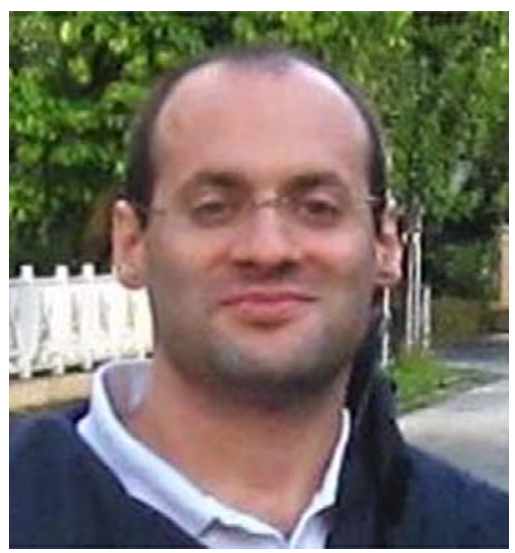

Ofir D. Rubin is senior lecturer in the Department of Public Policy and Administration at BenGurion University of the Negev, Israel. Ofir holds an MSc in agricultural economics and management from the Hebrew University of Jerusalem and a $\mathrm{PhD}$ in economics from Iowa State University. His research interests include economic modelling of food and energy markets and their interactions, agricultural trade and the performances of these markets in conjunction with firms' strategic behaviour and policy regulation. 